ORIGINAL ARTICLE

\title{
Erythromycin as a prokinetic agent in preterm neonates: a systematic review
}

\author{
S Patole, S Rao, D Doherty
}

See end of article for authors' affiliations ......................

Correspondence to: Dr Patole, Department of Neonatal Paediatrics, KEM Hospital for Women, University of Western Australia, Perth, Western Australia 6008; skpatole@ hotmail.com

Accepted

23 December 2005

Published Online First 17 May 2005

Background: It often takes several days or even weeks to establish full enteral feeds (FEFs) in preterm, especially extremely low birthweight neonates because of feed intolerance related to gastrointestinal hypomotility. Clinical trials of erythromycin as a prokinetic agent in preterm neonates have reported conflicting results.

Aim: To systematically review the efficacy and safety of erythromycin as a prokinetic agent in preterm neonates.

Methods: Only randomised controlled trials in preterm neonates (gestation $\leqslant 37$ weeks) were considered eligible for inclusion. The primary outcome was the time to reach FEFs of $150 \mathrm{ml} / \mathrm{kg} /$ day. The secondary outcomes included the incidence of erythromycin related adverse effects such as diarrhoea, cardiac arrhythmias, and hypertrophic pyloric stenosis. No restrictions were applied on the dose (low: 3-12 mg/ $\mathrm{kg} /$ day; antimicrobial: $\geqslant 12 \mathrm{mg} / \mathrm{kg} / 6-8$ hours) and route (oral or intravenous) and mode (prophylactic or rescue) of administration. The standard methodology for systematic reviews was followed. A subgroup analysis was preplanned based on the dose and mode of drug administration.

Results: Seven trials (three prophylaxis, four rescue) with various doses, routes and modes of administration, and durations of erythromycin treatment and different results were found to be eligible for inclusion in the analysis. Meta-analysis could not be performed, as specific data were either inadequate or not available.

Conclusion: The conflicting trial results may be explained by differences in dose and route and mode of administration of erythromycin and in gastrointestinal motor responses in the presence of different feeding conditions - for example, fasting $v$ fed state, intermittent $v$ continuous feeds. Gestational and postnatal ages during erythromycin treatment are also important.

$P$ ostnatal growth restriction has been recently recognised as a major and almost universal issue in preterm, especially extremely low birthweight neonates. ${ }^{1-7}$ Optimising enteral nutrition in preterm neonates, however, is not easy because of the common occurrence of feed intolerance due to gastrointestinal hypomotility ("ileus of prematurity") and the risk of necrotising enterocolitis, a potentially devastating illness. It is not uncommon to take several days or even weeks to establish full enteral feeds (FEFs) in high risk preterm neonates. Given this evidence and also the adverse effects associated with prolonged use of total parenteral nutrition, ${ }^{8} 9$ establishing FEFs quickly in high risk preterm neonates has become a priority in neonatal intensive care.

The gastrointestinal motor effects of erythromycin are well documented in experimental and clinical studies. ${ }^{10-16}$ After the early positive reports, the use of erythromycin as a prokinetic agent became fairly common in neonatal nurseries until recently. ${ }^{17-20}$ An earlier systematic review that focused only on the use of low dose erythromycin (3-12 mg/kg/day) in preterm neonates $\leqslant 36$ weeks gestational age with feeding tolerance did not find any eligible studies at the time. ${ }^{21}$ The lack of a clear understanding of the basis of its prokinetic action, however, has recently resulted in a plethora of clinical trials using different doses, routes and modes of administration, and durations of treatment. Most of these trials used surrogate markers of gastrointestinal motility such as gastric residuals and time to FEFs to assess the efficacy of erythromycin as a prokinetic agent. Not surprisingly the results are conflicting. This systematic review aimed to study the efficacy and safety of erythromycin as a prokinetic agent in preterm neonates.

\section{METHODS}

Trials in preterm neonates with gestation $\leqslant 37$ weeks were considered eligible for inclusion. The primary outcome of interest was the time taken to reach FEFs of $150 \mathrm{ml} / \mathrm{kg} /$ day. The secondary outcomes of interest included the following: (a) erythromycin related adverse effects such as diarrhoea, cardiac arrhythmias, potentiation of theophylline toxicity, late onset infections, and hypertrophic pyloric stenosis; $(b)$ duration of total parenteral nutrition; $(c)$ duration of hospital stay; (d) weight at discharge from hospital; $(e)$ incidence of necrotising enterocolitis of stage 2 or worse. ${ }^{22}{ }^{23}$ No restrictions were applied on the dose (low: 3-12 mg/kg/day; antimicrobial: $\geqslant 12 \mathrm{mg} / \mathrm{kg} / 6-8$ hours) or route (oral or intravenous) or mode (prophylactic or rescue) of administration. The Cochrane Central Register of Controlled Trials (Central, The Cochrane Library, Issue 4, 2002), Medline, Embase, Cinahl databases, and proceedings of the Pediatric Academic Societies (published in Pediatric Research from 1980), European Society for Pediatric Research (ESPR) were searched in December 2003 and again in June 2004. Proceedings of the first and the second World Congress of Pediatric Gastroenterology, Hepatology, and Nutrition were also checked. The reference lists of identified randomised controlled trials, and personal files were searched. No language restriction was applied. The following key words were used: enteral, erythromycin feeding, neonates, and infants. Authors were contacted for additional specific data for meta-analysis or clarification of data. Data were independently extracted by the first two investigators and cross checked by all investigators to avoid any errors. Any

Abbreviations: FEF, full enteral feed; $M M C$, migrating motor complex 
Table 1 Summary of studies on erythromycin as a prokinetic agent in preterm neonates (prophylactic approach)

\begin{tabular}{|c|c|c|c|}
\hline & \multicolumn{2}{|c|}{ Antimicrobial dose $(n=149)$} & \multirow[b]{2}{*}{ Low dose $(n=43)^{26}$} \\
\hline & Patole ef $a l^{24}$ & Stenson et $\left.a\right|^{25}$ & \\
\hline $\begin{array}{l}\text { Number } \\
\text { Dose (mg/kg/dose) } \\
\text { Route } \\
\text { Duration } \\
\text { Authors' conclusion }\end{array}$ & $\begin{array}{l}73 \\
12 \text { every } 6 \mathrm{~h} \\
\text { Intragastric } \\
\text { Till FEFs or } 14 \text { days } \\
\text { Not useful }\end{array}$ & $\begin{array}{l}76 \\
15 \text { every } 8 \mathrm{~h} \\
\text { Intravenous } \\
7 \text { days } \\
\text { Not useful }\end{array}$ & $\begin{array}{l}43 \\
2.5 \text { every } 6 \mathrm{~h} \\
\text { Oral } \\
10 \text { days } \\
\text { Useful }\end{array}$ \\
\hline
\end{tabular}

inconsistencies were sorted out after discussions and agreement. Assessment of study quality was based on the guidelines of the Cochrane Neonatal Review Group. Low and antimicrobial doses of erythromycin have been known to have different effects on the gastrointestinal motility. The clinical implications of the prophylactic versus rescue approach are different and especially important, and the definition and significance of signs of "feed intolerance" are not clear. A subgroup analysis was therefore preplanned on the basis of the dose and mode of administration of erythromycin.

\section{RESULTS}

A total of seven studies involving 359 neonates were found eligible for inclusion in the analysis. ${ }^{24-30}$ Tables $1-6$ show the characteristics and quality assessment of these studies. Two of the three studies involving the prophylactic approach $(n=192)$ used the antimicrobial dose, whereas the third used the low dose of erythromycin. Three of the four studies involving the rescue approach $(n=167)$ used the low dose, whereas the fourth used the antimicrobial dose of erythromycin. The doses, routes and modes of administration, and durations of erythromycin treatment as well as the feeding protocols and definition of feed intolerance varied in these trials (tables 5 and 6) Specific data required for meta-analysis (raw data/mean (SD)) were either inadequate or not available from certain authors. ${ }^{25}{ }^{26}{ }^{29}$ In one case, the authors could not provide the data, as their manuscript was not yet published. ${ }^{30}{ }^{31}$ There was no reply from authors in one case. ${ }^{27}$ Meta-analysis thus could not be performed.

\section{DISCUSSION}

The results of our systematic review indicate considerable variation in the use of erythromycin as a prokinetic in preterm neonates, making it difficult to reach any clear conclusions or recommendations. The trial designs, results, and authors' conclusions reflect the poorly understood prokinetic actions of erythromycin under different conditions of use-for example, low versus antimicrobial dose-as well as the urgent need for preventing/minimising feed intolerance in preterm neonates. The issue of erythromycin related adverse effects also cannot be addressed adequately given the small sample sizes and insufficient data on long term follow up.

The dose (low versus antimicrobial) and route (intragastric versus intravenous) and mode (prophylactic versus rescue) of administration of erythromycin as well as the fasting versus fed state of the neonates has to be considered carefully before interpreting the results of such studies. The gestational and postnatal age $\mathrm{e}^{32}$ at exposure to erythromycin, the type of feeds (breast milk versus formula), ${ }^{33}$ method of feeding (intermittent boluses versus continuous infusion), the rate of bolus feed infusion, ${ }^{35}$ and the definition and severity of feed intolerance ${ }^{36}$ are also equally important.

The choice between prophylactic and rescue approach seems to be clear. Given that mild to moderate feed intolerance is almost universal in high risk preterm, especially extremely low birthweight neonates, prophylactic use of erythromycin will expose almost this entire population of neonates to a drug with adverse effects such as hypertrophic pyloric stenosis and cardiac arrest. ${ }^{37-42}$ Researchers have already suggested that neonatologists should limit the use of erythromycin as a rescue rather than prophylactic treatment. ${ }^{28}{ }^{29}$

The oral route may be preferred for drug administration because all erythromycin related, life threatening, and fatal cardiac complications have been associated with the intravenous route. The safety dose limit of intravenous erythromycin in preterm neonates has also not been determined yet. ${ }^{43}$ The choice between antimicrobial and low dose is, however, difficult. Exposure to antimicrobial doses for $\geqslant 14$ days in neonates up to 2 weeks old has been associated with a 10-fold increase in the risk of hypertrophic pyloric stenosis. ${ }^{38}$ Oral administration of a low dose on the other hand may result in inadequate serum concentrations with no prokinetic effects. Studies comparing serum concentrations and gastrointestinal motor effects after different doses and routes of administration of erythromycin may thus be useful in preterm neonates with "significant" feed intolerance beyond 2 weeks of life. Careful attention to the postnatal age and type, mode, and method of feeding is needed in the design of such studies.

Erythromycin is a competitive motilin receptor agonist with high affinity for motilin receptors and mimics the

Table 2 Summary of studies on erythromycin as a prokinetic agent in preterm neonates (rescue approach)

\begin{tabular}{|c|c|c|c|c|}
\hline & \multirow{2}{*}{$\begin{array}{l}\text { Antimicrobial } \\
\text { dose }(n=56)^{27}\end{array}$} & \multicolumn{3}{|l|}{ Low dose $(n=111)$} \\
\hline & & El Hennawy ef al ${ }^{29}$ & $\mathrm{Ng}$ et $\left.a\right|^{28}$ & Cairns ef al ${ }^{3031}$ \\
\hline $\begin{array}{l}\text { Number } \\
\text { Dose }(\mathrm{mg} / \mathrm{kg} / \text { dose) } \\
\text { Route } \\
\text { Duration } \\
\text { Authors' conclusion }\end{array}$ & $\begin{array}{l}56 \\
12.5 \text { every } 6 \mathrm{~h} \\
\text { Intragastric } \\
14 \text { days } \\
\text { Useful }\end{array}$ & $\begin{array}{l}27 \\
1.5 \text { every } 6 \mathrm{~h} \\
\text { Intragastric } \\
8 \text { days } \\
\text { Not useful }\end{array}$ & $\begin{array}{l}24 \\
5 \text { every } 8 \mathrm{~h} \\
\text { Intragastric } \\
\text { Till } 1 \text { week after FEFs } \\
\text { Not useful }\end{array}$ & $\begin{array}{l}60 \\
3 \text { every } 6 \mathrm{~h} \\
\text { Intravenous } \\
\text { Till FEFs } \\
\text { Not useful }\end{array}$ \\
\hline
\end{tabular}


Table 3 Erythromycin as a prophylactic prokinetic agent in preterm neonates

\begin{tabular}{|c|c|c|c|c|c|c|}
\hline & \multicolumn{4}{|c|}{ Antimicrobial dose $(n=149)$} & & \\
\hline & \multicolumn{2}{|l|}{ Patole et $\left.a\right|^{24}$} & \multicolumn{2}{|l|}{ Stenson et $\left.a\right|^{25}$} & \multicolumn{2}{|c|}{ Low dose $(n=43)^{26}$} \\
\hline & Erythromycin & Placebo & Erythromycin & Placebo & Erythromycin & Placebo \\
\hline Number & 36 & 37 & 35 & 41 & 22 & 21 \\
\hline Gestation (weeks) & $29(27-30)$ & $30(27-31)$ & $28(24-30)$ & $29(23-30)$ & $28.6(2.2)$ & $29.3(1.7)$ \\
\hline Birth weight $(\mathrm{g})$ & $1232(906-1493)$ & $1280(890-1562)$ & $1025(590-2300)$ & $1050(500-1670)$ & $1226(380)$ & $1355(228)$ \\
\hline $\begin{array}{l}\text { Age at starting } \\
\text { treatment (days) }\end{array}$ & $5(3-7.7)$ & $5(3-7.5)$ & 1 & 1 & NA & NA \\
\hline $\begin{array}{l}\text { Time to FEFs after } \\
\text { enrolment (days) }\end{array}$ & $3.9(3.4-5.9)$ & $4.3(3.4-6.8)$ & $8(5-12)$ & $9(6-14)$ & $6(2.3)$ & $7.9(3.5)$ \\
\hline $\begin{array}{l}\text { Postnatal age at FEFs } \\
\text { (days) }\end{array}$ & $9.5(7-13)$ & $11(7-16)$ & $9.72(5.96)$ & $11.86(9.02)$ & NA & NA \\
\hline $\begin{array}{l}\text { Time to regain birth } \\
\text { weight (days) }\end{array}$ & NA & NA & NR & NR & $14.9(2.6)$ & $15.3(16.6)$ \\
\hline Discharge weight (g) & NA & NA & NR & NR & NA & NA \\
\hline Duration of treatment & Till FEFs or 14 days & Till FEFs or 14 days & 7 days & 7 days & 10 days & 10 days \\
\hline Duration of TPN & NA & NA & NA & NA & NA & NA \\
\hline $\begin{array}{l}\text { Duration of hospital } \\
\text { stay (days) }\end{array}$ & $43(30.5-57)$ & $46(23.7-69)$ & NR & NR & NA & NA \\
\hline$\geqslant$ Stage 2 NEC & 0 & 0 & 2 & 4 & 1 & 1 \\
\hline Cardiac arrhythmia & 0 & 0 & $\overline{0}$ & 0 & 0 & 0 \\
\hline Diarrhoea & NA & NA & NR & NR & NA & NA \\
\hline Late onset sepsis & NA & NA & NR & NR & NA & NA \\
\hline Theophylline toxicity & 0 & 1 & 0 & 0 & 0 & 0 \\
\hline $\begin{array}{l}\text { Hypertrophic pyloric } \\
\text { stenosis }\end{array}$ & 0 & 0 & 0 & 0 & NA & NA \\
\hline Death & 0 & 0 & 7 & 8 & 1 & 1 \\
\hline
\end{tabular}

Values are median (range) or mean (SD).

FEFs, Full enteral feeds; TPN, total parenteral nutrition; NEC, necrotising enterocolitis; NA, not available; NR, not recorded.

effects of motilin on the proximal gastrointestinal tract. ${ }^{44}{ }^{45} \mathrm{It}$ is also known to enhance the release of endogenous motilin, and stimulate cholinergic nerves of the gut at both preganglionic and postganglionic levels, leading to the release of calcium, which initiates contractions of the gut smooth muscle that are responsible for the forward propulsion of nutrients. ${ }^{44-51}$ Understanding the two basic patterns (fasting versus fed) of small intestinal motor activity and the influence of gestational age on it is necessary before using erythromycin as a prokinetic agent in preterm neonates. ${ }^{52-54} \mathrm{~A}$ cyclical pattern of antral and intestinal contractile activity, called migrating motor complex (MMC), progresses from the

Table 4 Erythromycin as a rescue prokinetic agent in preterm neonates

\begin{tabular}{|c|c|c|c|c|c|c|c|c|}
\hline & \multirow{2}{*}{\multicolumn{2}{|c|}{ Antimicrobial dose $(n=56)^{27}$}} & \multicolumn{6}{|c|}{ Low dose $(n=111)$} \\
\hline & & & \multicolumn{2}{|c|}{ El Hennawy et $a^{29}$} & \multicolumn{2}{|l|}{$\mathrm{Ng}$ et al ${ }^{28}$} & \multicolumn{2}{|c|}{ Cairns ef al ${ }^{30} 31$} \\
\hline & Erythromycin & Placebo & Erythromycin & Placebo & Erythromycin & Placebo & Erythromycin & Placebo \\
\hline Number & 27 & 29 & 15 & 12 & 13 & 11 & 32 & 28 \\
\hline Gestation (weeks) & $29.6(28.6-30.7)$ & $29.3(27.5-31.0)$ & $29(3)$ & $29(2)$ & $27.1(1.9)$ & $27.5(2.9)$ & $27.8(1.9)$ & $27.5(1.8)$ \\
\hline Birth weight (g) & $1180(985-1395)$ & $1160(1004-1389)$ & $1178(416)$ & $1212(527)$ & $806.3(215.6)$ & $981.6(285.4)$ & NA & NA \\
\hline $\begin{array}{l}\text { Age at starting } \\
\text { treatment (days) }\end{array}$ & 14 & 14 & $24(13)$ & $26(13)$ & $19.7(9)$ & $17.3(5.3)$ & NA & NA \\
\hline $\begin{array}{l}\text { Time to FEFs after } \\
\text { enrolment (days) }\end{array}$ & $13.5(8-22)$ & $25(16-33)$ & NA & NA & $24.9(2.9)^{*}$ & $30.8(4.1)^{\star}$ & $13.0(14.1)$ & $26.5(20.5)$ \\
\hline $\begin{array}{l}\text { Postnatal age at } \\
\text { FEFs (days) }\end{array}$ & NA & NA & $31(15)$ & $36(16)$ & $46.6(18)$ & $52.1(17.5)$ & NA & NA \\
\hline $\begin{array}{l}\text { Time to regain birth } \\
\text { weight (days) }\end{array}$ & NA & NA & NA & NA & $12.8(4.4)$ & $16.8(6.2)$ & NA & NA \\
\hline $\begin{array}{l}\text { Discharge weight } \\
\text { (g) }\end{array}$ & NA & NA & NA & NA & NR & NR & NA & NA \\
\hline $\begin{array}{l}\text { Duration of } \\
\text { treatment (days) }\end{array}$ & 14 & 14 & 8 & 8 & $28.4(7.1)$ & $33.6(9.4)$ & Till FEFs & Till FEFs \\
\hline $\begin{array}{l}\text { Duration of TPN } \\
\text { (days) }\end{array}$ & NA & NA & NA & NA & $39.4(13.8)$ & $43.3(18.3)$ & NA & NA \\
\hline $\begin{array}{l}\text { Duration of hospital } \\
\text { stay (ddys) }\end{array}$ & $73(64-97)$ & $86(64-109)$ & NA & NA & $98.3(35.9)$ & $99.6(58.6)$ & NA & NA \\
\hline$\geqslant$ Stage 2 NEC & 0 & 0 & NA & NA & 0 & 1 & NA & NA \\
\hline Cardiac arrhythmia & 0 & 0 & NA & NA & 0 & 0 & NA & NA \\
\hline Diarrhoea & NA & NA & NA & NA & NA & NA & NA & NA \\
\hline Late onset sepsis & 11 & 9 & NA & NA & 3 & 3 & NA & NA \\
\hline $\begin{array}{l}\text { Theophylline } \\
\text { toxicity }\end{array}$ & NA & NA & NA & NA & 0 & 0 & NA & NA \\
\hline $\begin{array}{l}\text { Hypertrophic pyloric } \\
\text { stenosis }\end{array}$ & 0 & 0 & NA & NA & 0 & 0 & NA & NA \\
\hline Death & 0 & 3 & 0 & 0 & 0 & 0 & NA & NA \\
\hline
\end{tabular}


Table 5 Assessment of study quality

\begin{tabular}{|c|c|c|c|c|c|c|c|}
\hline & $\begin{array}{l}\text { Patole } \\
\text { et }\left.a\right|^{24}\end{array}$ & $\begin{array}{l}\text { Stenson } \\
\text { ef }\left.a\right|^{25}\end{array}$ & Oei \& Lui ${ }^{26}$ & $\mathrm{Ng}$ et $a l^{27}$ & $\begin{array}{l}\text { ElHennawy } \\
\text { ef }\left.a\right|^{29}\end{array}$ & $\mathrm{Ng}$ et $a l^{28}$ & $\begin{array}{l}\text { Cairns } \\
\text { ef }\left.a\right|^{30} \text { 31* }\end{array}$ \\
\hline $\begin{array}{l}\text { Blinding of } \\
\text { randomisation }\end{array}$ & Yes & Yes & Yes & Yes & Yes & Yes & Yes \\
\hline $\begin{array}{l}\text { Allocation } \\
\text { concealment }\end{array}$ & Yes & No & Yes & Yes & Yes & Yes & Not clear \\
\hline $\begin{array}{l}\text { Blinding of } \\
\text { outcome } \\
\text { assessment }\end{array}$ & Yes & No & Yes & Yes & Yes & Yes & Not clear \\
\hline Follow up & Complete & Complete & Not complete & Complete & Complete & Complete & $\begin{array}{l}\text { ? Not } \\
\text { complete }\end{array}$ \\
\hline $\begin{array}{l}\text { Sample size } \\
\text { calculation }\end{array}$ & Yes & None† & Yes & Yes & Yes & Yes & Not clear \\
\hline $\begin{array}{l}\text { *Published as } \\
\text { †Reported dat } \\
\text { preventing chr }\end{array}$ & $\begin{array}{l}\text { tract only } \\
\text { re observ }\end{array}$ & ons reco & post hoc fror & randomi & controlled & l of & omycin for \\
\hline
\end{tabular}

antrum to the ileum during fasting. It has been described as the housekeeper of the bowel, removing the indigestible solids and bacteria from the upper gastrointestinal tract. In adult humans, these MMCs consist of four phases. Phase I consists of no contractile activity, which is sequentially interrupted by periods of irregular contractions (phase II), followed by regular contractions at a rate of three per minute in the atrium or 12 per minute in the duodenum (phase III), and a brief period of irregular contractions before the return of quiescence (phase IV). The cycle repeats every 45180 minutes. It is important to know that the MMC is interrupted by a meal, with an indistinct pattern of irregular contractions appearing until hours after the meal. ${ }^{52-54}$ By 34 weeks these complexes are of variable length, with clear intervals and being increasingly propagated. The mature MMC at this stage has a periodicity of 20-40 minutes and is interrupted by feeding. ${ }^{55}$ Ittmann et al $l^{57}$ have shown that fasting antral motor activity per se is comparable in preterm and term neonates and that the degree of antroduodenal coordination improves simultaneously towards term. Except for the considerably shorter periodicity, the MMC has adult characteristics at term gestation.

Despite considerable research, the important issue of fasting versus fed status of the neonates in question remains neglected. As discussed above, MMCs are a property only of the fasting state, and are interrupted by a meal. If the prokinetic effects of erythromycin are indeed related primarily to induction of MMCs, they are expected to be unpredictable in neonates on intermittent bolus feeds given the difficulty in separating fasting versus fed states in relation to drug administration. The issue is even more complicated in the presence of continuous feeds where there is effectively no "fasting" state. The rate of infusion of intermittent bolus feeds may also be related to feed tolerance. Duodenal motor responses in preterm neonates fed by slow intragastric infusion over 120 minutes are more like those in adults, and their gastric contents are emptied faster and more completely than when they are fed with a rapid bolus. ${ }^{35}$ This approach may provide clinical benefits by improving gastric hypomotility residuals. The problem of lower intestinal, including colonic, hypomotility, however, will not be solved. ${ }^{36}$

The prokinetic effects of erythromycin are reported to be dose dependent. ${ }^{12}{ }^{1351}$ At antimicrobially ineffective, intravenous low doses $(1-3 \mathrm{mg} / \mathrm{kg})$, premature MMCs are induced, whereas at higher $(10 \mathrm{mg} / \mathrm{kg})$ doses this effect is lost because of mechanisms that are poorly understood. The presence of two different types of motilin receptors may explain the difference in responses to a low or antimicrobial dose of erythromycin. ${ }^{58-60}$ The "neural" receptor is stimulated by a low dose that triggers the MMCs. ${ }^{59}$ The "muscle"

Table 6 Feeding details in studies of erythromycin as a prokinetic agent in preterm neonates

\begin{tabular}{|c|c|c|c|c|}
\hline Study & Type & Method & Increments & Definition of feed intolerance \\
\hline Patole et $a l^{24}$ & EBM/preterm formula & $\begin{array}{l}\text { Intragastric 1-2 hourly bolus } \\
\text { feeds; prone, head elevation } \\
\text { position }\end{array}$ & Maximum $24 \mathrm{ml} / \mathrm{kg} /$ day & $\begin{array}{l}\text { Bile stained gastric residuals, abdominal } \\
\text { distension, vomiting }\end{array}$ \\
\hline Stenson et $a l^{25}$ & EBM & Intragastric hourly bolus feeds & $1 \mathrm{ml}$ until full feeds & $\begin{array}{l}\text { Not defined clearly; net enteral balance was } \\
\text { assessed: NG feed volume minus the NG } \\
\text { aspirate volume }\end{array}$ \\
\hline Oei \& Lui ${ }^{26}$ & EBM/formula & Intragastric 2 hourly bolus feeds & $\leqslant 30 \mathrm{ml} / \mathrm{kg} /$ day & $\begin{array}{l}\text { Abdominal distension; repeated large } \\
\text { aspirates; gastric residuals }>30 \% \text { of } \\
\text { previous } 6 \text { hours of feeds }\end{array}$ \\
\hline $\mathrm{Ng}$ et $\mathrm{al}^{27}$ & EBM/preterm formula & Intragastric hourly bolus feeds & $0.5-1 \mathrm{ml} / \mathrm{h} /$ day & $\begin{array}{l}\text { Vomiting > twice in } 24 \mathrm{~h} \text {; gastric residuals } \\
>50 \% \text { of previous } 4 \mathrm{~h} \text { on two occasions } \\
\text { within a day; repeated regurgitations; } \\
\text { suspected NEC or aspiration pneumonia }\end{array}$ \\
\hline ElHennawy et al ${ }^{29}$ & EBM/preterm formula & Intragastric bolus feeds & $20 \mathrm{ml} / \mathrm{kg} /$ day & $\begin{array}{l}\text { Severe abdominal distension ( }>15 \% \text { of } \\
\text { baseline abdominal girth); gastric residuals } \\
>25 \% \text { of fed volume; frank blood in stools }\end{array}$ \\
\hline $\mathrm{Ng}$ et $a l^{28}$ & EBM/preterm milk formula & $\begin{array}{l}\text { Intragastric bolus feeds; } \\
\text { continuous feeds if } 50 \% \text { of } \\
\text { bolus feeds not tolerated } 2 \text { weeks } \\
\text { after starting feeds; prone, head } \\
\text { elevated position }\end{array}$ & $\begin{array}{l}<10 \mathrm{ml} / \mathrm{kg} / \text { day during } \\
\text { first week } \\
<20 \mathrm{ml} / \mathrm{kg} / \text { day later }\end{array}$ & $\begin{array}{l}\text { Vomiting > twice in } 24 \mathrm{~h} \text {; gastric residuals } \\
>25 \% \text { of preceding } 4 \mathrm{~h} \text { on two occasions; } \\
\text { repeated regurgitations; suspected NEC or } \\
\text { aspiration pneumonia }\end{array}$ \\
\hline${ }^{*}$ Cairns et $a l^{30} 31$ & Not available & Not available & Not available & Not available \\
\hline
\end{tabular}

*Study presented as abstract, ${ }^{30}{ }^{31}$ paper not published yet.

EBM, Expressed breast milk; NG, nasogastric. 
receptor on the other hand is stimulated by higher doses of erythromycin triggering antral contractions and inhibiting MMCs. ${ }^{60}$ Beneficial prokinetic effects, however, have been reported at therapeutic or high doses of intravenous and oral erythromycin. Researchers have proposed that effects of the drug are influenced by the nature of the underlying disorder. ${ }^{59-64}$ These findings, however, may not necessarily apply to preterm neonates as these studies were conducted in either full term neonates and children or adults.

The effect of erythromycin on gastric antral motility/ emptying may explain the clinical benefits in very preterm neonates in whom MMCs are expected to be either immature or absent. Tomomasa et al ${ }^{15}$ have studied this issue in healthy preterm neonates (gestation 23-30 weeks, birth weight 825$1408 \mathrm{~g}$ ) who were 6-31 days old. They infused $0.75 \mathrm{mg} / \mathrm{kg}$ erythromycin intravenously for 15 minutes and compared gastric and duodenal contractions for 30 minutes between before and after the initiation of erythromycin infusion. The migrating complex was not present in these neonates and was not induced by erythromycin. However, erythromycin significantly increased non-propagating antral clusters of contractions in all six neonates. The antral motility index increased fourfold, indicating the presence of functioning motilin receptors in preterm neonates. Tomomasa et al ${ }^{65}$ have also studied the effect of oral erythromycin $(10 \mathrm{mg} v 3 \mathrm{mg})$ in neonates (postnatal age 5-100 days, weight 2.5-4 kg) with mild to moderate gastric emptying delay while on $\geqslant 40 \mathrm{ml}$ of milk feeds. After aspirating and discarding gastric residuals, neonates were given either erythromycin $(10 \mathrm{mg}(\mathrm{n}=8)$, $3 \mathrm{mg}(\mathrm{n}=6))$ or an equal volume of distilled water on the first day during measurements. The order of the drugs was reversed on the second day of the study. Oral erythromycin at a dose of $10 \mathrm{mg}$ but not at $3 \mathrm{mg}$ significantly increased gastric emptying compared with control measurements. This effect was not explained by an increase in the number of antral contractions. The researchers proposed that either an increase in the tone of the proximal stomach or a decrease in the pyloric tone may have been responsible for such results. Findings such as these may be the basis of the improvement in feed intolerance noted by researchers using the "rescueoral antimicrobial dose" approach. ${ }^{27}$ Jadcherla et al, ${ }^{32}$ on the other hand, have reported that intragastric low dose erythromycin $(0.75-3 \mathrm{mg} / \mathrm{kg})$ failed to induce phase III MMCs in neonates $<31$ weeks gestation. It, however, induced them in a dose dependent manner in neonates with gestational age $\geqslant 32$ weeks $(p<0.05)$. Erythromycin significantly increased the amplitude and frequency of antral contractions in term neonates and significantly increased the duodenal contraction amplitude in older preterm and term neonates, but these effects were absent from younger preterm neonates. They concluded that early use of erythromycin as a prokinetic agent may not be useful in very preterm neonates, partially useful in older preterm neonates, and useful in full term neonates. ${ }^{53}$ ElHennawy et al ${ }^{29}$ have also reported that low dose $(1.5 \mathrm{mg} / \mathrm{kg})$ intragastric erythromycin did not improve gastrointestinal motor function or feed tolerance in the short or the long term in preterm neonates. It is quite possible that such negative results are related to the low intragastric doses with resultant inadequate serum erythromycin concentrations for any prokinetic effect to occur. However, differences in neonatal characteristics including gestational/postnatal age and feeding type/methods may also be related.

In summary, current data indicate that the use of erythromycin should be reserved for only a very small subset of high risk preterm neonates with persistent/severe feed intolerance while limiting the duration of exposure and ensuring long term follow up. The definition and interpretation of the manifestations of "feed intolerance" are not clear. ${ }^{36}$ However, the need for prokinetic agents in preterm neonates is probably influenced considerably by the degree of our tolerance to feed intolerance. The recent decline in the use of prokinetics such as erythromycin in preterm neonates indicates tolerance towards feed intolerance and/or an increased awareness of the drug related side effects. ${ }^{66}$ Development of newer compounds with better safety profiles may mean that the chapter on macrolides as prokinetics in preterm neonates may not be closed yet. ${ }^{45} 67$

\section{ACKNOWLEDGEMENTS}

We acknowledge Dr Takeshi Tomomasa for his critical comments on effects of erythromycin.

\section{Authors' affiliations}

S Patole, S Rao, Department of Neonatal Paediatrics, King Edward Memorial Hospital for Women, University of Western Australia, Perth, Western Australia

D Doherty, Women and Infants Research Foundation at King Edward Memorial Hospital for Women and School of Women's and Infant's Health at University of Western Australia

Competing interests: none declared

\section{REFERENCES}

1 Clark RH, Thomas P, Peabody J. Extrauterine growth restriction remains a serious problem in prematurely born neonates. Pediatrics 2003;111:986-90.

2 Sweet MP, Hodgman JE, Pena I, et al. Two-year outcome of infants weighing 600 grams or less at birth and born 1994 through 1998. Obstet Gynecol 2003;101:18-23.

3 Steward DK, Pridham KF. Growth patterns of extremely low-birth-weight hospitalized preterm infants. J Obstet Gynecol Neonatal Nurs 2002;31:57-65.

4 Embleton NE, Pang N, Cooke RJ. Postnatal malnutrition and growth retardation: an inevitable consequence of current recommendations in preterm infants? Pediatrics 2001; 107:270-3.

5 Radmacher PG, Looney SW, Rafail ST, et al. Prediction of extrauterine growth retardation (EUGR) in WVLBW infants. J Perinatol 2003;23:392-5.

6 Cooke RJ, Ainsworth SB, Fenton AC. Postnatal growth retardation: a universal problem in preterm infants. Arch Dis Child Fetal Neonatal Ed 2004;89:F428-30.

7 Ehrenkranz RA, Younes N, Lemons JA, et al. Longitudinal growth of hospitalized very low birth weight infants. Pediatrics 1999;104:280-9.

8 Kaufman SS, Gondolesi GE, Fishbein TM. Parenteral nutrition associated liver disease. Semin Neonatol 2003;8:375-81.

9 Donnell SC, Taylor N, van Saene HK, et al. Infection rates in surgical neonates and infants receiving parenteral nutrition: a five-year prospective study. $J$ Hosp Infect 2002;52:273-80.

10 Itoh Z, Suzuki T, Nakaya M, et al. Gastrointestinal motor-stimulating activity of macrolide antibiotics and analysis of their side effects on the canine gut. Antimicrob Agents Chemother 1984;26:863-9.

11 Itoh Z, Nakaya M, Suzuki T, et al. Erythromycin mimics exogenous motilin in gastrointestinal contractile activity in the dog. Am J Physiol 1984;247: G688-94.

12 Otterson MF, Sarna SK. Gastrointestinal motor effects of erythromycin. Am J Physiol 1990;259:G355-63.

13 Tomomasa T, Kuroume T, Arai $\mathrm{H}$, et al. Erythromycin induces migrating motor complex in human gastrointestinal tract. Dig Dis Sci 1986;31:157-61.

14 Zara G, Quin XY, Pilot M, et al. Response of the human gastrointestinal tract to erythromycin. J Gastrointest Motil 1991;3:26-31.

15 Tomomasa T, Miyazaki M, Koizumi T, et al. Erythromycin increases gastric antral motility in human premature infants. Biol Neonate 1993;63:349-52.

16 Jadcherla SR, Klee G, Berseth CL. Regulation of migrating motor complexes by motilin and pancreatic polypeptide in human infants. Pediatr Res 1997:42:365-9.

17 Simkiss DE, Adams IP, Myrdal U, et al. Erythromycin in neonatal postoperative intestinal dysmotility. Arch Dis Child Fetal Neonatal Ed 1994;71:F128-9.

18 Kubota M, Nakamura T, Motokura T, et al. Erythromycin improves gastrointestinal motility in extremely low birthweight infants. Acta Paediatr Jpn 1994;36:198-201

$19 \mathrm{Ng} \mathrm{PC}$, Fok TF, Lee CH, et al. Erythromycin treatment for gastrointestinal dysmotility in preterm infants. J Paediatr Child Health 1997;33:148-50.

20 Su BH, Lin HC, Peng CT, et al. Effect of erythromycin on feeding intolerance in very low birth weight infants: a preliminary observation. Zhonghua Min Guo Xiao Er Ke Yi Xue Hui Za Zhi 1998;39:324-6.

$21 \mathrm{Ng} \mathrm{E}$, Shah V. Erythromycin for feeding intolerance in preterm infants. Cochrane Database Syst Rev 2001 ;(2):CD001815.

22 Bell MJ, Ternberg JL, Feigin RD, et al. Neonatal necrotizing enterocolitis. Therapeutic decisions based upon clinical staging. Ann Surg 1978;187: 1-7.

23 Wlash MC, Kliegman RM. Necrotising enterocolitis: treatment based on staging criteria. Pediatr Clin North Am 1986;33:179-201. 
24 Patole SK, Almonte R, Kadalraja R, et al. Can prophylactic oral erythromycin reduce time to full enteral feeds in preterm neonates? Int J Clin Pract 2000;54:504-8.

25 Stenson BJ, Middlemist L, Lyon AJ. Influence of erythromycin on establishment of feeding in preterm infants: observations from a randomised controlled trial. Arch Dis Child Fetal Neonatal Ed 1998;79:F212-14.

26 Oei J, Lui K. A placebo-controlled trial of low-dose erythromycin to promote feed tolerance in preterm infants. Acta Paediatr 2001;90:904-8.

$27 \mathrm{Ng}$ PC, So KW, Fung KS, et al. Randomised controlled study of oral erythromycin for treatment of gastrointestinal dysmotility in preterm infants. Arch Dis Child Fetal Neonatal Ed 2001;84:F177-82.

$28 \mathrm{Ng} \mathrm{SC}$, Gomez JM, Rajadurai VS, et al. Establishing enteral feeding in preterm infants with feeding intolerance: a randomized controlled study of low-dose erythromycin. J Pediatr Gastroenterol Nutr 2003;37:554-8.

29 ElHennawy AA, Sparks JW, Armentrout D, et al. Erythromycin fails to improve feeding outcome in feeding-intolerant preterm infants. J Pediatr Gastroenterol Nutr 2003;37:281-6.

30 Cairns P, Craig S, Tubman R, et al. Randomised controlled trial of low-dose erythromycin in preterm infants with feed intolerance [abstract]. Pediatr Res May, 2002:A2209.

31 Cairns P, Craig S, Tubman R, et al. Randomised controlled trial of low-dose erythromycin in preterm infants with feed intolerance [abstract]. Arch Dis Child 2002;86 (suppl I):G24.

32 Jadcherla SR, Berseth CL. Effect of erythromycin on gastroduodenal contractile activity in developing neonates. J Pediatr Gastroenterol Nutr 2002;34:16-22.

33 Tomomasa T, Hyman PE, Itoh K, et al. Gastroduodenal motility in neonates: response to human milk compared with cow's milk formula. Pediatrics 1987:80:434-8.

34 Cavell B. Gastric emptying in infants fed human milk or infant formula. Acta Paediatr Scand 1981;70:639-41

35 de Ville K, Knapp E, Al-Tawil Y, et al. Slow infusion feedings enhance duodenal motor responses and gastric emptying in preterm infants. Am J Clin Nutr 1998;68:103-8.

36 Jadcherla SR, Kliegman RM. Studies of feeding intolerance in very low birth weight infants: definition and significance. Pediatrics 2002;109:516-17.

37 Sorensen HT, Skriver MV, Pedersen L, et al. Risk of infantile hypertrophic pyloric stenosis after maternal postnatal use of macrolides. Scand J Infect Dis 2003;35:104-6.

38 No authors listed. More on erythromycin and pyloric stenosis. Arch Dis Child 2002;86:250

39 Cooper WO, Griffin MR, Arbogast P, et al. Very early exposure to erythromycin and infantile hypertrophic pyloric stenosis. Arch Pediatr Adolesc Med 2002; 156:647-50

40 Mahon BE, Rosenman MB, Kleiman MB. Maternal and infant use of erythromycin and other macrolide antibiotics as risk factors for infantile hypertrophic pyloric stenosis. J Pediatr 2000;139:380-4.

41 Gouyon JB, Benoit A, Betremieux P, et al. Cardiac toxicity of intravenous erythromycin lactobionate in preterm infants. Pediatr Infect Dis $J$ $1994 ; 13: 840-1$.

42 Farrar HC, Walsh-Sukys MC, Kyllonen K, et al. Cardiac toxicity associated with intravenous erythromycin lactobionate: two case reports and a review of the literature. Pediatr Infect Dis J 1993;12:688-91.

43 Gouyon JB. The use of erythromycin lactobionate to facilitate the postpyloric passage of tubes in children. J Pediatr Gastroenterol Nutr 1992;14:120.

44 Peeters T, Matthiis G, Depoortere I, et al. Erythromycin is a motilin receptor agonist. Am J Physiol 1989;257:G470-4.

45 Itoh Z, Suzuki T, Nakaya M, et al. Structure-activity relation among macrolide antibiotics in initiation of interdigestive migrating contractions in the canine gastrointestinal tract. Am J Physiol 1985;248:G320-5.
46 Qin XY, Pilot MA, Thompson $\mathrm{H}$, et al. Effects of cholinoceptor and 5 hydroxytryptamine 3 receptor antagonism on erythromycin-induced canine intestinal motility disruption and emesis. Br J Pharmacol 1993;108:44-9.

47 Holle GE, Steinbach E, Forth W. Effects of erythromycin in dog upper gastrointestinal tract. Am J Physiol 1992;263:G52-59.

48 Bani M, Colsovich B, Florentin F, et al. Analysis of the motor stimulating effect of erythromycin on gastrointestinal tract in vitro. Hepatogastroenterology 1988;35:196

49 Itoh Z, Omura S. Motilide, a new family of macrolide compounds mimicking motilin. Dig Dis Sci 1987;32:915.

50 Pennathur A, Tran A, Cioppi M, et al. Erythromycin strengthens the defective lower esophageal sphincter in patients with gastroesophageal reflux disease. Am J Surg 1994;167:169-73.

51 Peeters TL. Erythromycin and other macrolides as prokinetic agents. Gastroenterology 1993;105:1886-99.

52 Malagelada JR, Camilleri M, Stanghellini V. Manometric diagnosis of gastrointestinal motility disorders. New York: Theime, 1986.

53 Code CF, Marlett JA. The interdigestive myo-electric complex of the stomach and small bowel of dogs. J Physiol 1975;246:289-309

54 Vantrappen G, Janssens J, Hellemans J, et al. The interdigestive motor complex of normal subjects and patients with bacterial overgrowth of the small intestine. J Clin Invest 1977;59:1 158-66.

55 Bryant MG, Buchan AM, Gregor M, et al. Development of intestinal regulatory peptides in the human fetus. Gastroenterology 1982;83:47-54.

56 Berseth CL. Gestational evolution of small intestine motility in preterm and term infants. J Pediatr 1989;115:646-51.

57 Ittmann PI, Amarnath R, Berseth CL. Maturation of antroduodenal motor activity in preterm and term infants. Dig Dis Sci 1992;37:14-19.

58 Parkman HP, Pagano AP, Vozzelli MA, et al. Gastrokinetic effects of erythromycin: myogenic and neurogenic mechanisms of action in rabbit stomach. Am J Physiol 1995;269:G418-26.

59 Tack J, Janssens J, Vantrappen G, et al. Effect of erythromycin on gastric motility in controls and in diabetic gastroparesis. Gastroenterology 1992;103:72-9.

60 Coulie B, Tack J, Peeters T, et al. Involvement of two different pathways in the motor effects of erythromycin on the gastric antrum in humans. Gut 1998;43:395-400.

61 Annese V, Janssens J, Vantrappen G, et al. Erythromycin accelerates gastric emptying by inducing antral contractions and improved gastroduodenal coordination. Gastroenterology 1992;102:823-8.

62 Janssens J, Peeters TL, Vantrappen G, et al. Improvement of gastric emptying in diabetic gastroparesis by erythromycin. Preliminary studies. N Engl J Med 1990;322:1028-31.

63 Cucchiara S, Minella R, Scoppa A, et al. Antroduodenal motor effects of intravenous erythromycin in children with abnormalities of gastrointestina motility. J Pediatr Gastroenterol Nutr 1997:24:411-18.

64 Urbain JL, Vantrappen G, Janssens J, et al. Intravenous erythromycin dramatically accelerates gastric emptying in gastroparesis diabeticorum and normals and abolishes the emptying discrimination between solids and liquids. J Nucl Med 1990;31:1490-3.

65 Tomomasa T, Tabata M, Nako Y, et al. The effect of oral erythromycin on gastric emptying in neonates with gastric retention [abstract]. Gastroenterology 1997;112(suppl):A839.

66 Patole S, Muller R. Enteral feeding of preterm neonates: a survey of Australian neonatologists. J Matern Fetal Neonatal Med 2004;16:309-14.

67 Hauben M, Amsden GW. The association of erythromycin and infantile hypertrophic pyloric stenosis: causal or coincidental? Drug Saf 2002;25:929-42. 